УДК $338.242+664.76$

DOI: $10.15673 /$ fie.v11i3.1456

\author{
Нікішина О.В. \\ доктор економічних наук, старший науковий співробітник \\ завідувач відділу ринкових механізмів та структур \\ Інститут проблем ринку та економіко-екологічних досліджень НАН України \\ Французький бульвар, 29, м. Одеса, Україна, 65044 \\ E-mail: ksenkych@gmail.com \\ ORCID ID: 0000-0002-7172-3551
}

\title{
ПРИНЦИПИ ФОРМУВАННЯ ЛОГІСТИЧНИХ ЛАНЦЮГІВ ТОВАРНИХ РИНКІВ: КОНВЕРГЕНЦІЯ ПІДХОДІВ
}

Стаття присвячена розробці багаторівневої системи принципів формування ефективних логістичних ланцюгів товарних ринків та зв'язків між їх ланками. Обґрунтовано доцільність конвергенції чотирьох наукових підходів (відтворювального, інтеграційного, регуляторного та концепції «зеленої» економіки) для конструювання системи принципів формування ринкових логістичних ланцюгів. Доведено, що зазначені наукові підходи взаємопов'язані між собою єдиною відтворювальною метою - розширене відтворення товароруху в логістичних ланцюгах товарних ринків, їх ефективне функціонування й розвиток у національній економічній системі. Розвинуто теоретичні положення логістики в частині визначення складових процесу управління ринковими логістичними ланцюгами. Обґрунтовано компоненти відтворювальної, інтеграційної, регуляторної та екологічної групи принципів фрормування ринкових логістичних ланцюгів, розкрито сутність принципів у науковому-прикладному вимірі. На підставі емпіричних досліджень визначено проблеми реалізації відтворювальних принципів формування ринкових ланцюгів в українських реаліях.

Ключові слова: принципи, підходи, логістичний ланцюг товарного ринку, розширене відтворення товароруху, додана вартість, матеріальний потік.

This work is licensed under a Creative Commons Attribution 4.0 International License http://creativecommons.org/licenses/by/4.0/

Постановка проблеми та їі зв'язок з важливими науковими та практичними завданнями. В умовах зовнішньої інтеграції та формування глобальних ланцюгів доданої вартості забезпечення стійкого відтворювального розвитку стратегічних товарних ринків формує перед органами влади завдання розбудови ефективних державно-приватних логістичних ланцюгів товарних ринків (далі - ЛЛТР). Такі ланцюги спроможні забезпечити розширене відтворення товароруху в ринку, зменшити втрати ресурсів і часу у процесі переміщення матеріальних потоків, оптимізувати внутрішні й зовнішні потокові процеси, зменшити логістичні «розриви», активізувати провідні логістичні ланки, переорієнтувати сировинні потоки на внутрішню переробку, збалансувати різні параметри товаропотоків у просторі й часі тощо. На відміну від логістики підприємств, орієнтованої на максимізацію доходів великих корпоративних об'єднань, ринкова логістика передбачає оптимізацію загальної доданої вартості у ланцюгу із забезпечення пріоритету економічних інтересів держави, як носія інтересів суспільства. Становлення ринкової логістики як науки обумовлює необхідність розробки їі методології, невід'ємною складовою якої постають принципи формування ЛЛТР.
Аналіз останніх публікацій по проблемі. Різним аспектам теорії і практики логістики присвячено праці учених О. П. Величко, Л.М. Гурч [1], Л.М. Докієнко [2], Л.В. Забуранної [3], В.І. Кацьми [4], Є. В. Крикавського, О.В. Мельник [5], Ю.В. Пономарьової, І.Г. Смирнова, Л.В. Фролової [6], Н.I. Чухрай та інших науковців. Основна увага ученими приділяється загальній теорії та особливостям транспортної, складської й виробничої логістики на мікрорівні. Питання формування та управління макрологістичними системами, зокрема ЛЛТР, залишаються недостатньо дослідженими. Становлення ринкової логістики, як науково-організаційного напрямку розвитку товарних ринків, обумовлює необхідність розробки відповідної методології, головною складовою якої $є$ принципи. Як основоположні начала, принципи надають єдності і логічності всій сукупності методів, способів, прийомів і методик пізнання, що входять до методології. Ці обставини обумовили мету і завдання даного дослідження.

Формулювання цілей дослідження. Мета статті - розробка системи принципів формування ЛЛТР і зв'язків між їх ланками - визначила низку завдань:

* Публікацію підготовлено в межах виконання НДР «Формування ефективної логістики товарних ринків» (№ держреєстрації 0119U000227) 
1) обгрунтувати доцільність конвергенції чотирьох наукових підходів для конструювання системи принципів формування ЛЛТР;

2) визначити компоненти відтворювальної, інтеграційної, регуляторної та екологічної групи принципів;

3) обгрунтувати природу і сутність принципів у науково-прикладному вимірі з акцентом на відтворювальну групу принципів.

Виклад основних результатів та їх обгрунтування. Проведені дослідження [7, 8, 9] природи, характерних ознак і властивостей товарного ринку, типології інтеграційних зв'язків між суб'єктами господарювання в секторному й ринковому вимірі вказують на дотичність і переплетення чотирьох наукових підходів у системі принципів формування ефективних логістичних ланцюгів товарних ринків та зв'язків між їх ланками (рис. 1).

Відтворювальний підхід є базовою методоло- гічною платформою для ринкової логістики. Він передбачає забезпечення розширеного відтворення товароруху в ЛЛТР, нарощування доданої вартості шляхом спрямування сировинних потоків на внутрішню переробку й організацію ефективного товароруху продуктів переробки у внутрішньому й зовнішньому вимірі.

Інтеграційний підхід фокусує увагу на становленні, розвитку й трансформації інтеграційних зв'язків між суб'єктами ланок ЛЛТР на засадах узгодження їх економічних інтересів. Інтеграційні зв'язки й взаємодії формують будову логістичного ланцюга товарного ринку, визначають його здатність до реалізації відтворювальної функції товароруху як у національній, так і глобальній економічній системі. Сучасний етап розвитку логістики визначається формуванням міжнародної системи товароруху. Врахування інтеграційних тенденцій знаходить прояв у нових логістичних підходах, зокрема, інноваційному [1].

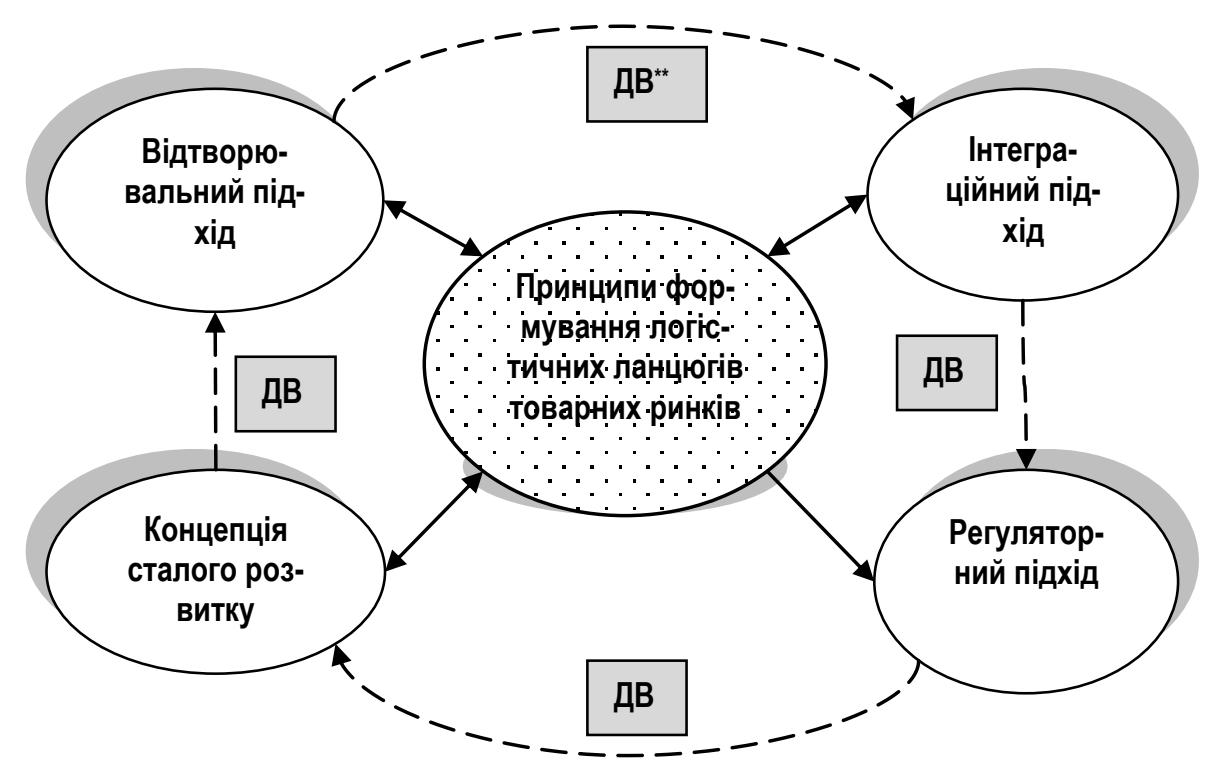

Рис. 1. Конвергенція наукових підходів у системі принципів формування ЛЛТР та зв'язків між їх ланками*

* авторська розробка

Умовні позначення: ДВ ${ }^{* *}-$ додана вартість.

Регуляторний підхід (див. рис. 1) передбачає керованість процесів формування, трансформації та розвитку ЛЛТР і зв'язків між їх ланками. Головною відмінністю ринкової логістики від логістики підприємств є активна роль держави у керуванні процесами товароруху, розбудові ефективних логістичних ланцюгів стратегічних товарних ринків, які забезпечують позитивний стабілізуючий вплив на головні параметри ринку (цінові, товарні, інвестиційні, інноваційні, структурні, часові, просторові тощо). На практиці у ланках ЛЛТР відбуваються постійні інтеграційні трансформації, які, реалізуючи економічні інтереси найсильніших суб'єктів ринку (зокрема, корпоративних структур), продукують логістичні «розриви»у ланцюгу, проявом яких може бути порушення рівноваги між попитом і пропозицією, цінові коливання, відторгнення малих виробників від логістичної інфраструктури, непропорційність міжсуб'єктного розподілу доходів тощо. Тому виникає необхідність реалізації виваженої ринкової політики держави, яка стихійні процеси логістизації спрямує в організоване русло збалансованого розвитку товарних ринків на засадах пріоритетності державних інтересів. Ось чому регуляторний підхід $є$ важливою складовою методологічного базису для системи принципів формування ЛЛТР та зв'язків між їх ланками.

Кероване формування й трансформація ринкових логістичних ланцюгів передбачає визначення компонентів управлінського процесу та їх характеристик (рис. 2). Об'єктом управління в ЛЛТР виступа- 
ють наскрізні матеріальні, фінансові та інформаційні потоки в межах єдиної матеріалопровідної системи (ланцюга). Мета управління носить відтворювальну природу й передбачає забезпечення розширеного відтворення товароруху. Розширене відтворення товароруху - це прискорення ринкового переміщення товару (від початкової до кінцевої ланки логістичного ланцюга товарного ринку) у зростаючих обсягах за рахунок узгодження параметрів наскрізного матеріального потоку між ланками ринкового логістичного ланцюга та нарощування його загальної доданої вартості. Головним критерієм розширеного відтворення товароруху є оптимізація створюваної в ЛЛТР ринкової доданої вартості.
Головні завдання управління зорієнтовані на зменшення або нівелювання логістичних «розривів» у ЛЛТР, оптимізацію внутрішніх і зовнішніх товаропотоків, скорочення втрат (часових, матеріальних, фінансових, трудових та ін.) у процесі товароруху, формування стійких зв'язків і взаємодій між суб'єктами ланок на основі узгодження їх економічних інтересів, забезпечення доступу малих і середніх виробників до матеріалопровідного ланцюга (див. рис. 2). Перелічені управлінські завдання відображають відтворювальний й інтеграційний підходи, а також концепцію сталого розвитку, що підсилює взаємозв'язки й конвергенцію між ними (див. рис. 1).

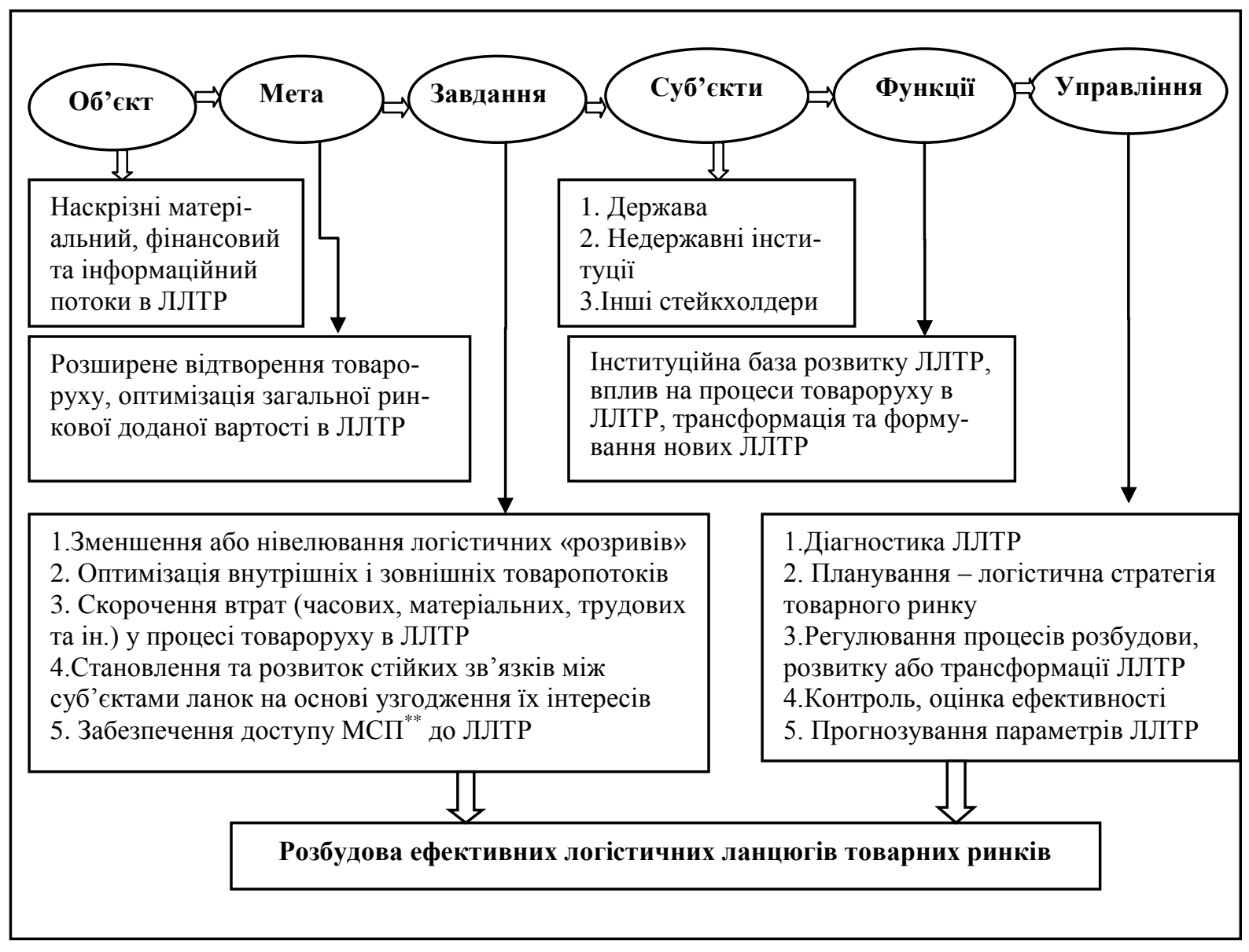

Рис. 2. Головні складові процесу управління ЛЛТР*

*авторська розробка

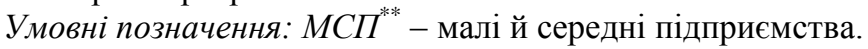

Головною організуючою та координуючою основою в цілісному матеріалопровідному ланцюгу державно-приватного типу повинна виступати держава в особі органів управління різних рівнів. Окрім них, до суб'єктів управління доцільно віднести профільні інституції, зокрема, об’єднання товаровиробників (виробничі й обслуговуючі кооперативи, асоціації тощо), які орієнтовані на підвищення їх конкурентоспроможності шляхом реалізації логістичних ефектів у ланцюгу. Третя група суб'єктів управління включає інших стейкхолдерів, якими можуть бути окремі суб'єкти, їх об'єднання, різноманітні корпорації та кластери, логістичні оператори та інші зацікавлені суб'єкти ринку.

Основними функціями держави в регулюванні ЛЛТР є формування сприятливого інституціонального середовища для їх розвитку, імплементація міжнародних стандартів товаропросування в вітчизняну практику, а також впровадження механізмів і інструментів досягнення цільових завдань логістичного управління. Шляхом впливу на процеси товароруху в ЛЛТР суб'єкти управління певним чином трансфор- 
мують матеріалопровідний ланцюг, змінюють його структуру та зв'язки між ланками, напрям руху товаропотоків, формують нові ланки та ланцюги, які $\epsilon$ більш ефективними порівняно $з$ діючими логістичними структурами.

Головними етапами логістичного управління є діагностика ЛЛТР, яка дозволяє визначити неефективні ланки й логістичні «розриви», планування й регулювання процесів розбудови, розвитку або трансформації матеріалопровідного ланцюга, контроль і оцінка ефективності управлінських заходів, прогнозування параметрів розвитку ринкових ланцюгів (див. рис. 2). Загалом логістичне управління спрямоване на забезпечення раціоналізації потокових процесів у межах керованого цілісного матеріалопровідного ланцюга.

Врахувавши дослідження вчених-логістів [3, 6], управління ЛЛТР можна трактувати як цілеспрямований вплив на просторово-часове балансування наскрізних матеріального, інформаційного й фінансового потоків $з$ метою оптимізації створюваної в ланцюгу ринкової доданої вартості та забезпечення розширеного відтворення товароруху. В українських реаліях функції щодо управління ЛЛТР, організації й планування товароруху у більшості випадків виконують великі корпоративні об'єднання. На підставі проведених емпіричних досліджень [7] доведено, що в аграрних ринках головними суб'єктами логістичного управління виступають трейдери й агрохолдинги, тоді як малі й середні первинні виробники, як правило, втрачають додану вартість у корпоративних логістичних ланцюгах, орієнтованих на максимізацію прибутків великих ринкових суб'єктів. Така обставина обумовлює необхідність розвитку кооперативних i державно-приватних логістичних ланцюгів аграрних ринків, здатних конкурувати 3 корпоративними ланцюгами в Україні.

Концеепиія сталого розвитку орієнтована на гармонізацію економічних, соціальних та екологічних цілей, їх реалізацію в єдиній системі. В 90-х рр. - на початку 2000 р. формується неологістика 2-го поко- ління, яка базується на теорії загальної відповідальності та концепції «зеленої» логістики [5]. «Зелена» логістика заснована на екологічно безпечних та ресурсозаощадливих процесах $\mathrm{i}$ технологіях. 3 позиції системного підходу науковці трактують «зелену» логістику як новий науковий напрямок, що передбачає застосування прогресивних технологій логістики і сучасного обладнання $з$ метою мінімізації забруднень навколишнього середовища й підвищення ефективності використання логістичних ресурсів [1].

Враховуючи активізацію програм національної адаптації 17 Цілей сталого розвитку та їх впровадження у всіх сферах економічної діяльності, у т.ч. логістичній, вважаємо за доцільне включення групи екологічних принципів до системи принципів формування ЛЛТР та зв'язків між їх ланками. Ефективна ринкова матеріалопровідна система повинна бути екологічною й ресурсозаощадливою, що обумовлює необхідність інтеграції екологічних параметрів у структуру логістичного управління.

Слід відзначити, що цільовий орієнтир ринкової логістики - оптимізація створюваної доданої вартості в ЛЛТР та розширене відтворення товароруху - притаманний усім науковим підходам (див. рис. 1), взаємозв'язок яких більш глибоко розкриває відтворювальний підхід та вказує на його багатогранність. Конвергенція чотирьох підходів у системі принципів формування ЛЛТР та зв'язків між їх ланками дозволяє максимально повно охопити полівекторні параметри розбудови та розвитку ринкової матеріалопровідної системи, що формує наукове підгрунтя для розробки методології оцінки й управління нею.

Відповідно до наукових підходів, обгрунтованих вище, автором пропонується виокремити 5 груп принципів формування логістичних ланцюгів товарних ринків та зв'язків між їх ланками: (1) загальні; (2) відтворювальні; (3) інтеграційні; (4) регуляторні; (5) екологічні. Систему принципів та їх характеристики узагальнено в таблиці 1. Розглянемо більш детально відтворювальну групу принципів.

Таблиця 1

Система принципів формування логістичних ланцюгів товарних ринків та зв'язків між їх ланками*

\begin{tabular}{|c|c|c|}
\hline Підxid & Принциипи & Характеристика \\
\hline \multirow{5}{*}{ 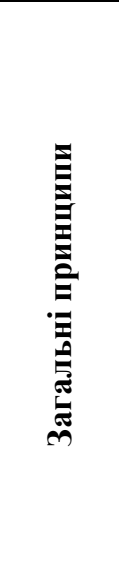 } & $\begin{array}{l}\text { 1. Системність } i \\
\text { комплексність }\end{array}$ & $\begin{array}{l}\text { Дослідження ЛЛТР як єдиної цілісної системи та як частини системи більш } \\
\text { високого рівня. Розширений аналіз елементів ЛЛТР та множини зв’язків і } \\
\text { взаємодій між ними у просторі й часі }\end{array}$ \\
\hline & $\begin{array}{l}\text { 2.Емерджен- } \\
\text { тність }\end{array}$ & $\begin{array}{l}\text { Властивість ЛЛТР виконувати цільову функцію, що реалізується тільки за- } \\
\text { гальною матеріалопровідною системою, а не її ланками. }\end{array}$ \\
\hline & $\begin{array}{l}\text { 3.Адекватність } i \\
\text { гнучкість }\end{array}$ & $\begin{array}{l}\text { Забезпечення можливості швидкого реагування ЛЛТР та врахування змін у } \\
\text { зовнішньому і внутрішньому економічному просторі, відповідність будови } \\
\text { й трансформацій ланцюгів сучасним закономірностям плинності ринкових } \\
\text { процесів відтворення }\end{array}$ \\
\hline & $\begin{array}{l}\text { 4. Об'єктивність } i \\
\text { точність }\end{array}$ & $\begin{array}{l}\text { Інформаційна база для формування та управління ЛЛТР повинна бути дос- } \\
\text { товірною, а її результати обгрунтовуватися точними аналітичними розраху- } \\
\text { нками }\end{array}$ \\
\hline & 5.Формалізація & $\begin{array}{l}\text { Отримання кількісних і якісних характеристик функціонування ринкових } \\
\text { логістичних ланцюгів }\end{array}$ \\
\hline
\end{tabular}


Продовження табл.1

\begin{tabular}{|c|c|c|}
\hline Пiдxid & Принципи & Характеристика \\
\hline \multirow{3}{*}{ 罢 } & $\begin{array}{l}\text { 1.3балансо- } \\
\text { ваність матеріа- } \\
\text { льних потоків }\end{array}$ & $\begin{array}{l}\text { Пропорційність розширеного відтворення товароруху в ЛЛТР. Забезпечення } \\
\text { пропорційності відтворення між ланками ринкового ланцюга, пропорційно- } \\
\text { сті матеріальних і фінансових потоків, просторових і часових параметрів } \\
\text { товаропросування і т.д. }\end{array}$ \\
\hline & $\begin{array}{l}\text { 2.Оптимізація } \\
\text { матеріальних по- } \\
\text { токів }\end{array}$ & $\begin{array}{l}\text { Цілеспрямоване управління наскрізним матеріальним потоком і ефективна } \\
\text { трансформація ЛЛТР для розширеного відтворення товароруху в ланцюгу } \\
\text { та максимізації ринкової доданої вартості }\end{array}$ \\
\hline & $\begin{array}{l}\text { 3. Повернення фi- } \\
\text { нансових потоків }\end{array}$ & $\begin{array}{l}\text { Надходження фінансових потоків у складові ланки ЛЛТР для забезпечення } \\
\text { розширеного відтворення товароруху як у межах ланок, так і в загальному } \\
\text { матеріалопровідному ланцюгу }\end{array}$ \\
\hline \multirow{2}{*}{$\begin{array}{l} \\
\\
\end{array}$} & $\begin{array}{l}\text { 1.Паритетність } \\
\text { інтеграційних вза- } \\
\text { ємодій }\end{array}$ & $\begin{array}{l}\text { Становлення та розвиток інтеграційних взаємодій між суб’єктами різних } \\
\text { ланок ЛЛТР на засадах узгодження їх економічних інтересів }\end{array}$ \\
\hline & $\begin{array}{l}\text { 2.Оптимізація } \\
\text { інтеграчійних } \\
\text { зв'язків }\end{array}$ & $\begin{array}{l}\text { Розвиток логістичних форм інтеграції, які спроможні оптимізувати наскрізні } \\
\text { потокові процеси у ЛЛТР (субконтрактація, кооперація та інші) }\end{array}$ \\
\hline \multirow{4}{*}{ 罚 } & $\begin{array}{l}\text { 1.Пріоритетність } \\
\text { економічних інте- } \\
\text { ресів держави }\end{array}$ & $\begin{array}{l}\text { Формування та управління ЛЛТР здійснюється не } 3 \text { позиції економічних } \\
\text { інтересів окремих суб’єктів ланок, а держави, як носія інтересів суспільства; } \\
\text { даний принцип є головним і в прийнятті управлінських рішень щодо цільо- } \\
\text { вого впливу на об’єкти регулювання }\end{array}$ \\
\hline & $\begin{array}{l}\text { 2. Цілеспрямо- } \\
\text { ваність }\end{array}$ & $\begin{array}{l}\text { Цільовий вплив регуляторних заходів держави на логістичні «розриви» то- } \\
\text { варного ринку для їх нівелювання (або зменшення), та на провідні ланки } \\
\text { ринкового логістичного ланцюга }\end{array}$ \\
\hline & 3. Ефективність & $\begin{array}{l}\text { Цільова орієнтацію регуляторних заходів на кінцевий економічний ефект - } \\
\text { максимізацію створюваної ринкової доданої вартості в ЛЛТР, }\end{array}$ \\
\hline & $\begin{array}{l}\text { 4.3воротного } \\
\text { зв'язку }\end{array}$ & $\begin{array}{l}\text { Позитивна зворотна реакція ЛЛТР на механізми й інструменти цільового } \\
\text { державного регулювання }\end{array}$ \\
\hline \multirow{3}{*}{ 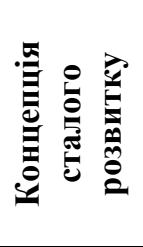 } & $\begin{array}{l}\text { 1.Мінімізація } \\
\text { втрат ресурсів }\end{array}$ & $\begin{array}{l}\text { Мінімізація втрат матеріальних ресурсів у процесі їх руху за ланками ЛЛТР, } \\
\text { у т.ч. скорочення втрат продовольства у ЛЛТР. }\end{array}$ \\
\hline & $\begin{array}{l}\text { 2.Замкненість } \\
\text { цииклів }\end{array}$ & $\begin{array}{l}\text { Формування замкнених ЛЛТР для забезпечення вторинної переробки мате- } \\
\text { ріалів і максимального повторного використання (рециклінг) }\end{array}$ \\
\hline & 3.Ринкова інклюзія & $\begin{array}{l}\text { Забезпечення вільного доступу малих і середніх виробників до ЛЛТР, зок- } \\
\text { рема, до ланки розподілу й реалізації продукції }\end{array}$ \\
\hline
\end{tabular}

*розроблено автором із використанням джерел [1-9]

Загальні принциипи притаманні будь-якій економічній системі, у т.ч. ринковим логістичним ланцюгам. До їх складу включено 5 основних принципів: (1) системність і комплексність; (2) емерджентність; (3) адекватність і гнучкість; (4) об'єктивність і точність; (5) формалізація.

Група відтворювальних принципів формування ЛЛТР включила три структуроутворюючі складові (див. табл. 1). Перший принцип передбачає збалансованість наскрізних матеріальних, інформаційних та фінансових потоків у єдиній матеріалопровідній системі в просторово-часових координатах. Енциклопедичні ресурси в ході визначення термінів «баланс», «збалансованість» акцентують увагу на забезпеченні пропорційності між елементами системи, підтримці іiі рівноваги, доведення до правильного співвідношення взаємно пов'язаних частин [10]. Тобто терміни «збалансування» й «пропорційність» $є$ в певній мірі синонімами. За теорією загальної рівноваги пропорційність виступає умовою досягнення повної і часткової рівноваги та нерівноважних станів; причинами двох останніх є диспропорції, які породжують дисбаланси [11, c.72].

У площині відтворювального підходу збалансованість економічної системи можна визначити як забезпечення пропорційності між виробництвом, розподілом, обміном і споживанням. Відтак, збалансованість наскрізних матеріальних потоків у ЛЛТР доцільно розглядати як забезпечення пропорційності розширеного відтворення товароруху в матеріалопровідній системі. Пропорції ринкової логістики виражають різні співвідношення в умовах виробництва, розподілу, обміну й споживання, тому можна виділити такі ознаки класифікації пропоричій: ні) й вартісні;

- за способом виміру: натуральні (матеріаль-

- за видом потоку: матеріальні, фінансові, інформаційні, сервісні;

- за структурою: співвідношення компонентів певної системи (ланок логістичного ланцюга, різних ринкових ланцюгів у глобальній логістичній системі тощо); 
- за територією: співвідношення ЛЛТР у глобальному, державному, регіональному, локальному вимірі.

У ринкових логістичних ланцюгах можна виділити різні сфери балансування, головними з яких є наступні:

- пропорції відтворення між ланками ланцюга (постачання, виробництва, зберігання, доробки, розподілу, реалізації, споживання, переробки відходів);

- пропорційність матеріальних і фінансових потоків у ланцюгу;

- обсяги певних видів матеріальних (сервісних) потоків;

- якісні й вартісні параметри матеріальних (сервісних) потоків;

- просторові й часові параметри товаропросування тощо.

На практиці в ЛЛТР відбувається порушення основних відтворювальних співвідношень, які ідентифікуються як диспропорції і призводять до дисбалансів. Так, в національній економіці мають місце зовнішньоекономічні структурні дисбаланси, проявом яких $\epsilon$ експорт сировинних товарів та імпорт продукції з високою доданою вартістю. Загальноекономічні структурні дисбаланси впливають на природу логістичних дисбалансів. У ЛЛТР просліджується причинно-наслідковий зв'язок між відтворювальними дисбалансами, що визначає можливість їх видового розподілу за ступенем впливу на пропорції відтворення на системні й похідні (є наслідком системних), глибинні й локальні (впливають на окремий елемент, а не систему).

Оцінка структурних показників має важливе значення для обгрунтування заходів підвищення ефективності функціонування ЛЛТР. На думку проф. Шинкарука Л.В., більшою мірою структурні компоненти (пропорції, диспропорціi), а не загальні величини дадуть змогу знайти шляхи вирішення кризи моделі глобального економічного розвитку [11, с.77].

Принции оптимізації матеріальних потоків у ринковому логістичному ланцюгу передбачає трансформацію матеріалопровідної системи для підвищення іiї ефективності та досягнення максимального значення критерію оцінки ефективності (див. табл. 1). Йдеться про оптимізацію наскрізних матеріальних, інформаційних та фінансових потоків у ЛЛТР для нарощування загальної ринкової доданої вартості, яка є головним ресурсом розширеного відтворення товароруху в ринкових логістичних ланцюгах різних рівнів.

Термін оптимізація (лат. optimus - найкращий) має декілька значень [10]: (1) вибір найкращого варіанту із можливих для досягнення найбільшої ефективності певного процесу з урахуванням заданих вимог і обмежень; (2) модифікація системи для підвищення іiі ефективності; (3) процес приведення системи в найкращий (оптимальний) стан.

Процес оптимізації наскрізних матеріальних, інформаційних та фінансових потоків у ЛЛТР передбачає цілеспрямоване управління потоковими проце- сами із дотриманням принципів регуляторного підходу, зокрема, принципу пріоритетності економічних інтересів держави. Даний принцип дозволяє об'єктивно визначити оптимум єдиного матеріалопровідного ланцюга. На практиці можливою є розбіжність локальних оптимумів цілей окремих ланок із глобальним оптимумом мети ЛЛТР. Так, нарощування створюваної у логістичному ланцюгу зернового ринку загальної доданої вартості досягається шляхом спрямування частини зернових потоків із експортної ланки в переробну, що супроводжується зменшенням прибутку в посередницькій ланці розподілу й зовнішньої реалізації, що не відповідає меті й інтересам їі суб'єктів, однак є необхідною умовою ефективної трансформації ринкового ланцюга для реалізації економічних інтересів держави на зерновому ринку у вигляді забезпечення відтворювального, соціального та податкового ефектів.

Можна виділити три характеристики оптимальності логістичної системи: (1) управління потоковими процесами; (2) стану або поведінки системи; (3) мети розвитку. Таким чином, оптимізацію наскрізного матеріального потоку у ЛЛТР можна трактувати як цілеспрямоване управління трансформацією структури існуючого ринкового ланцюга або формуванням структури нового логістичного ланцюга. Метою управління є забезпечення розширеного відтворення товароруху в матеріалопровідній системі, а оптимумом - нарощування створюваної в ЛЛТР загальної доданої вартості. Відтак, маємо подвійну природу логістичної оптимізацїі, яка полягає в цілеспрямованому управлінні наскрізним матеріальним потоком i ефективній трансформації ЛЛТР для розширеного відтворення товароруху в ринковому ланцюгу.

Слід відзначити, що на мікрорівні в якості головного оптимуму логістичної системи учені розглядають ефект синергізму [3, 6]. На макрорівні в ринковій логістиці доцільно встановлювати оптимум, що має відтворювальну природу, зокрема, нарощування загальної доданої вартості матеріалопровідного ланцюга.

Процес оптимізації наскрізних матеріальних потоків у ЛЛТР включає 5 головних етапів:

1) дослідження головних чинників впливу на організацію руху наскрізних матеріальних і фінансових потоків у ЛЛТР; ланцюга;

2) оптимізація структури (будови) ринкового

3) синхронізація наскрізних матеріальних потоків ЛЛТР у часі;

4) оптимізація розподілу матеріальних потоків у розрізі ланок ;

5) оцінка ефективності оптимізації наскрізних матеріальних потоків.

Одним із найскладніших $є$ процес оптимізації структури (будови) ЛЛТР із цільовою орієнтацією на реалізацію мети загального матеріалопровідного ланцюга, що досягається шляхом виваженого управлінського впливу держави із дотриманням регуляторних принципів (див. табл. 1). Оптимізація структури ЛЛТР пов'язана із формуванням його окремих ланок, 
що забезпечують найбільш ефективні шляхи та форми переміщення й зберігання товарно-матеріальних цінностей. Загалом оптимальна будова ЛЛТР повинна забезпечувати раціоналізацію потокових процесів у межах керованої матеріалопровідної системи.

Оптимізація розподілу матеріальних потоків між ланками ЛЛТР передбачає вибір найефективнішого варіанту розподілу запасів, внутрішніх і зовнішніх логістичних потоків із забезпеченням пріоритету економічних інтересів держави. Напрями такої оптимізації визначаються у залежності від природи логістичних «розривів» певного товарного ринку та впроваджуються регуляторними механізмами, що відповідають пріоритетам державної ринкової політики. Так, для оптимізації розподілу наскрізних матеріальних потоків у логістичному ланцюгу українського ринку зерна та продуктів його переробки необхідно впровадження механізмів стимулювання внутрішньої зернопереробки, тобто спрямування частини зовнішніх зернопотоків у переробну ланку з подальшим експортом товарів 3 високою доданою вартістю.

Оцінка ефективності оптимізації наскрізних матеріальних потоків у ЛЛТР здійснюється з використанням системи показників, які визначають зниження ресурсних витрат, часових втрат, зростання результативності потокового процесу, досягнення цільового орієнтиру матеріалопровідного ланцюга, зокрема, нарощування ринкової доданої вартості (див. рис. 2).

Принщии повернення фінансових потоків передбачає надходження фінансових потоків у складові ланки ЛЛТР для забезпечення розширеного відтворення товароруху як у межах ланок, так і в загальному матеріалопровідному ланцюгу (див. табл. 1). Зворотний рух фінансових потоків є невід'ємною складовою відтворювального колообігу споживчої вартості товару. Формування ефективного ринкового логістичного ланцюга передбачає повернення фінансових потоків, що супроводжують наскрізний матеріальний потік, у його ланки в певні терміни та обсягах, які забезпечують процес розширеного відтворення ресурсів. Недотримання даної умови порушує збалансованість наскрізного матеріального потоку, зокрема, пропорцій відтворення між ланками ланцюга, пропорційність співвідношення матеріальних і фінансових потоків у його межах, якісні й цінові параметри логістичних потоків та ін. Відтак, маємо взаємопов'язаність відтворювального принципу збалансованості матеріальних потоків із принципом повернення фінансових потоків у ланцюгу (див. табл. 1).
Одним із напрямків сучасної логістики є фінансова логістика, яка розглядається як інноваційна стратегія управління матеріалопровідною системою. Логістика фінансових потоків є інтеграцією логістики й фінансового менеджменту, тому її природу й цільові орієнтири учені визначають крізь призму управління формуванням, розподілом та використанням фінансових потоків у логістичній системі для ії збалансованого розвитку [2]. Водночас логістичний підхід передбачає привнесення завдань оптимізації, тому мету фінансової логістики доцільно визначати як оптимізацію управління фінансовим потоком, що підсилить її логістичну складову.

У ринковій логістиці фінансова складова передбачає оптимізацію управління наскрізним фінансовим потоком в ЛЛТР та оптимізацію руху й розподілу фінансових ресурсів між ланками. Йдеться про досягнення просторово-часової збалансованості фінансових потоків, формування міжланкових балансів рентабельності, доданої вартості, інвестицій тощо, які забезпечують розширене відтворення товароруху в матеріалопровідному ланцюгу.

В українських реаліях принцип повернення фінансових потоків досить часто порушується. На думку експертів, найбільш «вузьким» місцем у розбудові логістичних ланцюгів вартості є вхідні інвестиційні потоки через небажання інвесторів фінансувати виробничі цикли, що мають тривалий термін окупності [12, с. 14]. 3 іншого боку, враховуючи домінуючий сировинний характер українського експорту, можна говорити про відтік (міграцію) значної частини доданої вартості та відсутність завершеного виробничого циклу у межах держави, що обумовлює зниження як обсягів фінансових потоків у ЛЛТР, так і можливості реінвестування доданої вартості у базові виробничі ланки ланцюгів.

На думку Хомина І.П. (і ми підтримуємо цю позицію), за рахунок створеної в аграрному секторі України доданої вартості відбувається фінансове донорство інших секторів вітчизняної й іноземної економік [13, с. 41]. Відтак, у логістичному ланцюгу агропродовольчих ринків відбувається відтік доданої вартості, іiї непропорційний перерозподіл між ланками, скорочення обсягів фінансового потоку у ресурсоутворювальну виробничу ланку. Дане твердження наочно підтверджує аналіз зовнішньоекономічного балансу аграрного сектору та економіки України (табл.2).

Зовнішньоекономічний баланс аграрного сектору та економіки України у 2005-2018 рр., млрд. дол. США*

\begin{tabular}{|l|c|c|c|c|c|c|c|c|c|c|c|}
\hline \multirow{2}{*}{ Показники } & \multicolumn{10}{|c|}{ Роки } & $\begin{array}{r}2018 \text { р. до } \\
2005 \text { р., } \\
\text { пункти }\end{array}$ \\
\cline { 2 - 13 } & 2005 & 2010 & 2011 & 2012 & 2013 & 2014 & 2015 & 2016 & 2017 & 2018 & \\
\hline $\begin{array}{l}\text { 1. Експорт агро- } \\
\text { продукції (1-14 } \\
\text { УКТЗЕД) }\end{array}$ & 2,43 & 6,59 & 6,47 & 10,18 & 9,96 & 9,75 & 8,79 & 8,87 & 10,32 & 11,10 & 4,6 \\
\hline $\begin{array}{l}\text { 2. Імпорт агроп- } \\
\text { родукції }\end{array}$ & 1,03 & 3,26 & 2,85 & 4,15 & 4,56 & 3,16 & 1,69 & 1,91 & 2,10 & 2,45 & 2,4 \\
\hline
\end{tabular}


Продовження табл. 2

\begin{tabular}{|c|c|c|c|c|c|c|c|c|c|c|c|}
\hline \multirow{2}{*}{ Показники } & \multicolumn{10}{|c|}{ Роки } & \multirow{2}{*}{$\begin{array}{c}2018 \text { р. до } \\
2005 \text { р., } \\
\text { пункти }\end{array}$} \\
\hline & 2005 & 2010 & 2011 & 2012 & 2013 & 2014 & 2015 & 2016 & 2017 & 2018 & \\
\hline $\begin{array}{l}\text { 3.Сальдо експо- } \\
\text { рту/імпорту } \\
\text { (Е/I) агропро- } \\
\text { дукції } \\
\end{array}$ & 1,40 & 3,34 & 3,62 & 6,03 & 5,40 & 6,59 & 7,10 & 6,96 & 8,22 & 8,65 & 6,2 \\
\hline $\begin{array}{l}\text { 4. Експорт зер- } \\
\text { нових культур }\end{array}$ & 1,38 & 2,47 & 3,62 & 7,00 & 6,37 & 6,54 & 6,06 & 6,07 & 6,50 & 7,24 & 5,2 \\
\hline $\begin{array}{l}\text { 5. Імпорт зерно- } \\
\text { вих культур }\end{array}$ & 0,50 & 0,15 & 1,04 & 1,72 & 1,89 & 1,12 & 0,55 & 0,63 & 0,73 & 0,92 & 1,8 \\
\hline $\begin{array}{l}\text { 6. Сальдо E/I } \\
\text { зернових куль- } \\
\text { тур }\end{array}$ & 0,88 & 2,32 & 2,58 & 5,28 & 4,48 & 5,42 & 5,51 & 5,45 & 5,77 & 6,32 & 7,1 \\
\hline $\begin{array}{l}\text { 7. Сальдо E/I } \\
\text { агропродукції } \\
\text { без зернових } \\
\text { культур } \\
\end{array}$ & 0,52 & 1,02 & 1,04 & 0,75 & $\mathbf{0 , 9 2}$ & 1,17 & 1,59 & 1,51 & 2,46 & 2,33 & 4,5 \\
\hline $\begin{array}{l}\text { 8. Експорт зага- } \\
\text { лом }\end{array}$ & 34,29 & 51,43 & 68,39 & 68,81 & 63,31 & 53,90 & 38,13 & 36,36 & 43,26 & 47,34 & 1,4 \\
\hline $\begin{array}{l}\text { 9. Імпорт зага- } \\
\text { лом }\end{array}$ & 36,14 & 60,74 & 82,61 & 84,66 & 76,96 & 54,43 & 37,52 & 39,25 & 49,61 & 57,14 & 1,6 \\
\hline $\begin{array}{l}\text { 10. Сальдо E/I } \\
\text { загалом }\end{array}$ & $-1,85$ & $-9,31$ & $\begin{array}{r}- \\
14,21\end{array}$ & $\begin{array}{c} \\
15,85 \\
\end{array}$ & $\begin{array}{c}- \\
13,65\end{array}$ & $-\mathbf{0 , 5 3}$ & 0,61 & $-2,89$ & $-6,34$ & $-9,80$ & 5,3 \\
\hline $\begin{array}{l}\text { 11. Сальдо E/I } \\
\text { без агропродук- } \\
\text { ціï }\end{array}$ & $-3,26$ & $-12,65$ & $-17,83$ & $-21,88$ & $-19,05$ & $-7,12$ & $-6,49$ & $-9,85$ & $-14,57$ & $-18,45$ & 5,7 \\
\hline
\end{tabular}

" розраховано автором за даними Державної служби статистики України [14].

У 2018 р. зовнішньоторговельне сальдо аграрної продукції склало 8,65 млрд. дол. США, збільшившись порівняно 32005 р. в 6,2 рази. Обсяг даного сальдо без зернових культур є майже вчетверо меншим - всього 2,33 млрд. дол. США (див. табл. 2). Відтак, додатне сальдо української аграрної продукції на $73 \%$ формує сальдо зернових культур. Загальний зовнішньоекономічний баланс України має від'ємне значення й досягає в 2018 р. -9,8 млрд. дол. США, що в 5,3 рази вище показника 2005 р. Водночас за умови виключення із зовнішньоторговельного балансу додатного сальдо аграрного сектору, дефіцит балансу досягне 18,45 млрд. дол. США, тобто вдвічі вище фактичного показника звітного року. За досліджуваний період у 2015 р. сальдо зовнішнього балансу вперше стало додатним (0,61 млрд. дол. США), однак тільки за рахунок аграрного сектору.

За розрахунками Хомина І.П, протягом 20102015 рр. аграрний сектор у розрахунку на 1 дол. США генерував у середньому 0,51 дол. чистого припливу іноземної валюти для України, тим часом як інші сектори - 0,32 дол. іiі чистої втрати [13, с. 45]. Тобто аграрний сектор безпосередньо фінансує валютою інші галузі України та опосередковано економіки інших країн. За умови спрямування обсягу додатного сальдо сільгосппродукції (див. табл. 2) на фінансування аграрного сектору можна було б забезпечити його технічне переозброєння [13].
На нашу думку, доказом існуючої непропорційності матеріальних і фінансових потоків у логістичному ланцюгу аграрної продукції є величина індикатора капіталомісткості валової доданої вартості (ВДВ) у сільському господарстві (таблиця 3). За даними Держстату, у 2017 р. частка аграрного сектору у ВДВ держави досягла 10,2\%, а питома вага даного сектору в загальній вартості основних засобів - близько $3 \%$, що на 7 \% менше рівня 2001 р. Порушення пропорцій виробництва й реінвестування доданої вартості обумовило низьке значення капіталомісткості ВДВ - 0,324 пункти, що вдвічі нижче рівня 2001 р.

За 2001-2017 pp. частка сільського господарства у ВДВ зменшилася на 4,18 \%, у вартості основних засобів - на 6,89\%, капіталомісткість - на 0,38 \%. Для порівняння: капіталомісткість ВДВ у переробній промисловості досягла 1,818 пункти в 2017 р., що в 5,6 рази вище показника в агарному секторі (див. табл. 3). Це обумовлено значно вищою часткою переробного сектору у загальній вартості основних засобів (21,9\%) порівняно 3 сільським господарством за одночасно приблизно однаковою часткою в ВДВ держави (12,1 \% в 2017 р.) [14]. Слід відзначити позитивну динаміку змін показника капіталомісткості ВДВ переробної промисловості - приріст склав 0,73 пункти. 
Таблиця 3

Динаміка капіталомісткості валової доданої вартості (ВДВ) у сільському господарстві та переробній промисловості"

\begin{tabular}{|c|c|c|c|c|c|c|c|c|c|c|c|}
\hline \multirow{2}{*}{ Показники } & \multicolumn{10}{|c|}{ Роки } & \multirow{2}{*}{$\begin{array}{c}+,- \\
(10-1)\end{array}$} \\
\hline & 2001 & 2005 & 2010 & 2011 & 2012 & 2013 & 2014 & 2015 & 2016 & 2017 & \\
\hline$A$ & 1 & 2 & 3 & 4 & 5 & 6 & 7 & 8 & 9 & 10 & 11 \\
\hline $\begin{array}{l}\text { 1.Частка сільсь- } \\
\text { кого господарст- } \\
\text { ва у ВДВ, \% }\end{array}$ & 14,41 & 9,18 & 7,40 & 8,15 & 7,76 & 8,69 & 10,15 & 12,06 & 11,73 & 10,23 & $-4,18$ \\
\hline $\begin{array}{l}\text { 2. Частка сільсь- } \\
\text { кого господарст- } \\
\text { ва у вартості ос- } \\
\text { новних засобів, } \\
\%\end{array}$ & 10,20 & 5,96 & 1,71 & 1,60 & 1,50 & 1,50 & 1,25 & 2,75 & 3,31 & $3,31^{* *}$ & $-6,89$ \\
\hline $\begin{array}{l}\text { 3.Капіталомісткі } \\
\text { сть ВДВ }{ }^{* * *} \text { у } \\
\text { сільському гос- } \\
\text { подарстві }(2 / 1)\end{array}$ & 0,708 & 0,649 & 0,230 & 0,196 & 0,194 & 0,173 & 0,123 & 0,228 & 0,282 & 0,324 & $-0,38$ \\
\hline $\begin{array}{l}\text { 4.Капіталомісткі } \\
\text { сть ВДВ у пере- } \\
\text { робній промис- } \\
\text { ловості }\end{array}$ & 1,091 & 0,979 & 0,810 & 0,741 & 0,606 & 0,518 & 0,450 & 1,822 & 1,794 & 1,818 & $+0,73$ \\
\hline
\end{tabular}

" розраховано автором за даними Державної служби статистики України [14];

*****: дані 2016 року;

***індикатор запропоновано автором.

Проведений аналіз рівнів і динаміки капіталомісткості ВДВ в сільськогосподарському та переробному секторах національної економіки, які ототожнюють базові аграрну та виробничу ланки ЛЛТР, вказує на процес реінвестування доданої вартості, створеної в аграрній ланці, в технічне оновлення інших ланок матеріалопровідного ланцюга, або відтік доданої вартості за його межі шляхом зростаючого сировинного експорту. Наведені розрахунки свідчать про порушення на практиці відтворювальних принципів формування ефективних ЛЛТР, зокрема, збалансованості матеріальних потоків у частині дотримання пропорційності товарних і фінансових потоків у ланцюгу, та повернення фінансових потоків, обумовлюючи необхідність державного впливу.

Виділена група відтворювальних принципів (див. табл. 1) стосується не тільки збалансування й оптимізації наскрізного матеріального потоку в ЛЛТР, а й відповідного йому інформаційного потоку, який рухається як у прямому, так і зворотному напрямі, тобто циркулює в логістичному ланцюгу. Управління наскрізним інформаційним потоком в ринкових ланцюгах орієнтовано на максимально ефективне використання внутрішньої і зовнішньої інформації для прийняття виважених і своєчасних рішень, які забезпечують досягнення мети матеріалопровідного ланцюга (див. рис. 2), вирішення низки тактичних або стратегічних завдань. Інформація формує аналітичну базу для діагностики стану ЛЛТР, прогнозування напрямів іiі розвитку й трансформації, ідентифікації логістичних «розривів», обгрунтування заходів управлінського впливу тощо. Також інформація забезпечує інформаційний обмін між суб'єктами різних ланок, є об'єднуючим елементом між ланками ринкового ланцюга.

До складу групи інтеграиійних принцииів формування ЛЛТР, яка впливає на його структуру, типи зв'язків між ланками та взаємодії між суб'єктами, автором віднесено два принципи (див. табл. 1). Принции паритетності інтеграиійних взаємодій базується на узгодженості (гармонізації) економічних інтересів суб'єктів різних ланок ринкового ланцюга. Принции оптимізації інтегращчійних зв'язків передбачає становлення та розвиток таких логістичних форм інтеграціï, які спроможні оптимізувати наскрізні потокові процеси у ЛЛТР з метою розширеного відтворення товароруху в його межах. Найбільш перспективними формами логістичної інтеграції в українських реаліях є субконтрактація й кооперація.

Регуляторний підхід до формування, трансформації й розвитку ЛЛТР передбачає керованість даних процесів на стратегічних ринках із дотриманням базового принципу пріоритетності економічних інтересів держави, як носія інтересів суспільства. На практиці даний принцип залишається нереалізованим, у ланцюгах корпоративного типу домінують інтереси найсильніших суб'єктів (корпорацій), наділених ринковою владою. Принции изілеспрямованості передбачає цільовий вплив регуляторних заходів держави на логістичні «розриви» товарного ринку для їх нівелювання (або зменшення), та на провідні ланки ринкового ланцюга. Глибина, масштаб і часові параметри регуляторного впливу залежать від його об'єкту. Так, регулювання логістичних «розривів», які ринок самостійно не може усунути, чинить стабілізуючий вплив на матеріалопровідну систему, тоді як активізація (розбудова) провідних ланок ланцюга - формуючий вплив. У логістичному ланцюгу ринку зерна 
та зернопереробки до потенційних об'єктів державного регулювання доцільно віднести логістичний «розрив» між аграрною ланкою (індивідуальний сектор) і ланкою зберігання й доробки товару, а також провідну переробну ланку.

Приниии ефективності державного регулювання передбачає цільову орієнтацію регуляторних заходів на кінцевий економічний ефект (оптимізація створюваної ринкової доданої вартості в ЛЛТР) та формування розвиненої системи інституцій та інститутів. В процесі впровадження даного принципу має місце розбіжність локальних ефектів окремих ланок iз загальним ефектом ринкового логістичного ланцюга. Принцип зворотного зв'язку орієнтований на досягнення позитивної зворотної реакції ЛЛТР на регуляторні механізми й заходи; інструментом його впровадження є моніторинг.

Група принципів сталого розвитку включила три компоненти (див. табл. 1): (1) мінімізація втрат ресурсів; (2) замкненість циклів; (3) ринкова інклюзія. Перший принцип передбачає мінімізацію втрат матеріальних ресурсів у процесі їх руху за ланками ЛЛТР, у т.ч. скорочення втрат продовольства у ланцюгах. Проведений аналіз засвідчив високий рівень частки післязбиральних втрат овочів і баштанних культур у загальному виробництві (10,8 \%), що є наслідком, зокрема, відсутності ланки зберігання й доробки продукції у логістичному ланцюгу [9]. Принщии замкненості изиклу орієнтований на формування замкнених ЛЛТР для забезпечення вторинної переробки матеріалів і їх повторного використання. В Україні індикатор частки спалених та утилізованих відходів у загальному обсязі утворених відходів склав 27,6\%, що на 7,4 \% нижче цільового індикатора 2020 р. Нерозвиненість інфраструктури повторного використання сировини є однісю із головних причин загострення екологічних проблем у сфері поводження з відходами.

Принщии ринкової інклюзї̈ передбачає забезпечення вільного доступу малих і середніх виробників до ЛЛТР, зокрема, до ланки розподілу й реалізації продукції. Інструментом впровадження даного принципу $є$ створення інклюзивних інституцій, зокрема, аграрних кооперативів. У цілому впровадження принципів «зеленої» логістики орієнтовано на перетворення ринкового логістичного ланцюга в інтегровану екологістичну систему, в межах якої здійснюються екологічно безпечні потокові процеси.

Висновки та перспективи подальших досліджень. У статті обгрунтовано доцільність конвер- генції чотирьох підходів (відтворювального, інтеграційного, регуляторного та концепції сталого розвитку) для конструювання багаторівневої системи принципів формування логістичних ланцюгів товарних ринків. Зазначені наукові підходи взаємопов'язані між собою єдиною відтворювальною метою - розширене відтворення товароруху в ЛЛТР, їх ефективне функціонування й розвиток у національній системі.

У ході дослідження дістали подальшого розвитку теоретичні положення в частині визначення складових процесу управління логістичними ланцюгами товарних ринків, зокрема суб'єктів і об'єкту управління, завдань і етапів управління 3 цільовою орієнтацію на забезпечення розширеного відтворення товароруху, які, на відміну від існуючих, передбачають участь держави у формуванні провідних ланок і ефективних ланцюгів стратегічних товарних ринків з метою оптимізації загальної, а не локальної доданої вартості, оптимізацію управління наскрізними матеріальними, інформаційними та фінансовими потоками (об'єкт управління) та їх просторово-часове балансування в ринкових ланцюгах.

Розроблена система принципів формування логістичних ланцюгів товарних ринків та зв'язків між їх ланками включила 5 груп принципів: загальні, відтворювальні, інтеграційні, регуляторні, екологічні. У статті детально досліджено природу відтворювальної групи принципів у науково-прикладному вимірі, визначено проблеми ї впровадження в українських реаліях.

Наукова новизна проведеного дослідження полягає в обгрунтуванні багаторівневої системи принципів формування ефективних ЛЛТР на основі конвергенції чотирьох наукових підходів, їх взаємозв'язку й взаємообумовленості, єдиної відтворювальної основи; розвитку теоретичних положень щодо компонентів процесу управління ринковими логістичними ланцюгами. Практичне значення результатів дослідження полягає в їх використанні як методологічного базису в ході розробки теоретикометодологічних засад оцінки ефективності функціонування ЛЛТР, обгрунтування механізмів формування й управління логістичними ланцюгами стратегічних товарних ринків держави. Перспективи подальших досліджень полягають у розширенні системи базових принципів формування ЛЛТР у розрізі різних наукових підходів, як складової методології ринкової логістики.

\section{Література}

1. Гурч Л.М., Хмара Л.Є. Розвиток «зеленої логістики» в Україні // Вісник Національного університету «Львівська політехніка». Логістика. 2014. № 811. С. 86-91.

2. Докієнко Л.М. Фінансова логістика на підприємстві: теоретичні аспекти // Економічний вісник НГУ. 2012. №3. С.121-126.

3. Забуранна Л.В. Логістичне управління підприємством: сутність та передумови розвитку // Сталий розвиток економіки. 2010. №7. С. 120-123.

4. Кацьма В.І. Сутність та роль логістичного управління в системі управління підприємством // Економічний аналіз. 2016. Т.2. №2. С.60-65. 
5. Мельник О.В. Нові концептуальні підходи в логістиці // Ефективна економіка. 2013. №2. URL: http://www.economy.nayka.com.ua/?op=1\&z=1825 (дата звернення 27.06.2019).

6. Фролова Л.В. Логістичне управління торговельним підприємством: теорія та методологія: автореф. дис. д-ра. екон. наук: спец. 08.07.05 «Економіка торгівлі та послуг». Донецьк, 2005. 39 с.

7. Логістика товарного ринку: монографія / за ред. Б. В. Буркинського, В. М. Лисюка. Одеса: ІПРЕЕД НАН України, 2018. 244 с.

8. Nikishyna, O. V. Methodical approach to the evaluation the efficiency of integrated commodity market: scientific report, Saarbrucken, Germany, LAMBERT Academic Publishing, 2017. 89 p.

9. Nikishyna O.V., Andryeyeva N.M., Lozova T.P. Assessment of indicators of responsible consumption and production in Ukraine in the context of "green" logistics. European journal of economics and management. Issue 1. Volume 5. Praha, 2019. PP. 278-287.

10. Економічна енциклопедія: у трьох томах. Т. 1 / Редкол. С. В. Мочерний (відп. ред.) та ін. Київ: ВЦ «Академія», 2000. 864 с.

11. Шинкарук Л.В. Структурний і соціальний аспекти оцінки пропорційності та диспропорційності в економіці // Економічний вісник. 2014. №4. С. 71-78.

12. Международная транспортная логистика в Украине: достижения ощутимы, но резервы роста огромны // Логистика: проблемы и решения. 2019. №1 (80). С. 13-17.

13. Хомин І.П. Аграрний сектор України - фінансовий донор вітчизняної та зарубіжних економік // Фінанси України. 2018. №4. С.41-55.

14. Офіційний сайт Державної служби статистики України. URL: http://www.ukrstat.gov.ua/ (дата звернення 27.06.2019).

Стаття надійшла 2.07.2019

Стаття прийнята до друку 16.07.2019

Доступно в мережі Internet 16.10.2019

\author{
Никишина О.В. \\ доктор экономических наук, старший научный сотрудник \\ заведующий отдела рыночных механизмов и структур \\ Институт проблем рынка и экономико-экологических исследований НАН Украины \\ Французский бульвар, 29, г.Одесса, Украина, 65044 \\ E-mail: ksenkych@gmail.com \\ ORCID ID: 0000-0002-7172-3551
}

\title{
ПРИНЦИПЫ ФОРМИРОВАНИЯ ЛОГИСТИЧЕСКИХ ЦЕПЕЙ ТОВАРНЫХ РЫНКОВ: КОНВЕРГЕНЦИЯ ПОДХОДОВ
}

Статья посвящена разработке многоуровневой системы принципов формирования эффективных логистических цепей товарных рынков и связей между их звеньями. Обоснована целесообразность конвергенции четырех научных подходов (воспроизводственного, интеграционного, регуляторного и концепции устойчивого развития) для конструирования системы принципов формирования рыночных логистических цепей. Доказано, что указанные научные подходы взаимосвязаны между собой единой воспроизводственной целью - расширенное воспроизводство товародвижения в логистических цепях товарных рынков, их эффрективное функционирование и развитие в национальной экономической системе.

Развиты теоретические положения логистики в части определения составляющих процесса управления рыночными логистическими цепями. Обоснованы компоненты воспроизводственной, интеграционной, регуляторной и экологической группы принципов фрормирования рыночных логистических цепей, раскрыта сущность принципов в научно-прикладном измерении с акцентом на воспроизводственные принципы.

Группа воспроизводственных принципов фрормирования логистических цепей товарных рынков включила три компоненты. Принцип сбалансированности сквозных материальных потоков предусматривает обеспечение пропорциональности расширенного воспроизводства товародвижения в рыночной цепи. Принцип оптимизации материальных потоков имеет двойственную природу, которая заключается в целенаправленном управлении сквозным материальным потоком и эфрфективной трансформации логистической цепи товарного рынка. Принцип возврата фринансовых потоков предусматривает поступление финансовых потоков в звенья для обеспечения расширенного воспроизводства товародвижения в логистической цепи. На основании эмпирических исследований определены проблемы реализации воспроизводственных принципов фрормирования рыночных цепей в украинских реалиях. 
Научная новизна исследования заключается в обосновании многоуровневой системы принципов формирования эффективных логистических цепей товарных рынков на основе конвергенции четырех научных подходов, их взаимосвязи и взаимозависимости, единой воспроизводственной основы, что фрормирует методологический базис для разработки механизмов управления логистическими цепями стратегических товарных рынков страны.

Ключевые слова: принципы, подходы, логистическая цепь товарного рынка, расширенное воспроизводство товародвижения, добавленная стоимость, материальный поток.

\author{
Nikishyna 0. \\ Doctor of Economics, Senior Researcher \\ Head of Department of Market Mechanisms and Structures \\ Institute of Market Problems and Economic \& Ecological Research \\ of National Academy of Sciences of Ukraine \\ Frantsuzskiy boulevard, 29, Odesa, Ukraine, 65044 \\ E-mail: ksenkych@gmail.com \\ ORCID ID: 0000-0002-7172-3551
}

\title{
PRINCIPLES OF FORMATION OF THE LOGISTIC CHAINS OF COMMODITY MARKETS: CONVERGENCE OF APPROACHES
}

The article is devoted to the development of a multilevel system of principles for the formation of effective logistic chains of commodity markets and connections between their links. The expediency of convergence of four scientific approaches (reproduction, integration, regulatory and concept of sustainable development) is substantiated to construct a system of principles for the formation of market logistics chains. It is proved that these scientific approaches are interconnected by a single reproduction goal - an expanded reproduction of goods movement in the logistic chains of commodity markets, their effective functioning and development in the national economic system.

The theoretical positions of logistics in the part of definition of components of process of management by market logistical chains have been developed. The components of the reproduction, integration, regulatory and ecological group of principles of formation of market logistic chains have been substantiated, the essence of principles in scientific and applied measurement with the emphasis on reproduction principles has been revealed.

A group of reproduction principles for the formation of commodity market logistics chains included three components. The principle of the balance of through material flows involves ensuring the proportionality of the extended reproduction of commodity movement in the market chain. The principle of optimization of material flows has a dual nature, which consists in the purposeful management of through material flow and effective transformation of the logistic chain of the commodity market. The principle of returning financial flows involves the admission of financial flows into the chain to ensure the expanded reproduction of goods movement in the logistics chain. On the basis of empirical researches the problems of realization of reproduction principles of formation of market chains in Ukrainian realities have been determined.

The scientific novelty of the research is to substantiate the multilevel system of principles of formation of effective logistic chains of commodity markets on the basis of convergence of four scientific approaches, their interconnection and interdependence, a single reproduction basis that forms the methodological basis for the development of mechanisms for managing of logistic chains of strategic commodity markets of the state.

Key words: principles, approaches, the logistic chain of the commodity market, expanded reproduction of commodity movement, added value, material flow.

\section{References}

1. Hurch, L. M., \& Khmara, L. Ye. (2014). Rozvytok «zelenoi lohistyky» v Ukraini. Visnyk Natsionalnoho Universytetu «Lvivska Politekhnika», (811), 86-91.

2. Dokiienko, L. M. (2012). Finansova lohistyka na pidpryiemstvi: teoretychni aspekty. Ekonomichnyi Visnyk NHU, (3), 121-126.

3. Zaburanna, L. V. (2010). Lohistychne upravlinnia pidpryiemstvom: sutnist ta peredumovy rozvytku. Stalyi Rozvytok Ekonomiky, (7), 120-123.

4. Katsma, V. I. (2016). Sutnist ta rol lohistychnoho upravlinnia v systemi upravlinnia pidpryiemstvom. Ekonomichnyi Analiz, 2(2), 60-65.

5. Melnyk, O. V. (2013). Novi kontseptualni pidkhody v lohistytsi. Efektyvna Ekonomika, (2). Retrieved June 27, 2019, from http://www.economy.nayka.com.ua/?op=1\&z=1825 
6. Frolova, L. V. (2005). Lohistychne upravlinnia torhovelnym pidpryiemstvom: teoriia ta metodolohiia. (Doctoral dissertation). [Abstract]. 1-39. (UMI No. Dokt. ekon. nauk: 08.07.05).

7. Burkynskyi, B. V., \& Lysiuk, V. M. (Eds.). (2018). Lohistyka tovarnoho rynku. Odesa: IPREED NAN Ukrainy.

8. Nikishyna, O. V. (2017). Methodical approach to the evaluation the efficiency of integrated commodity market [Report]. (pp. 1-89). Saarbrucken: LAMBERT Academic Publishing.

9. Nikishyna, O. V., Andryeyeva, N. M., \& Lozova, T. P. (2019). Assessment of indicators of responsible consumption and production in Ukraine in the context of "green" logistics. European Journal of Economics and Management, 5(1), 278-287.

10. Mochernyi, S. V. (Ed.). (2000). Ekonomichna entsyklopediia (Vol. 1). Kyiv: VTs «Akademiia».

11. Shynkaruk, L. V. (2014). Strukturnyi i sotsialnyi aspekty otsinky proportsiinosti ta dysproportsiinosti v ekonomitsi. Ekonomichnyi Visnyk, (4), 71-78.

12. Mezhdunarodnaia transportnaia logistika v Ukraine: dostizheniia oshchutimy, no rezervy rosta ogromny. (2019). Logistika: Problemy i Resheniia, (1 (80), 13-17.

13. Khomyn, I. P. (2018). Ahrarnyi sektor Ukrainy - finansovyi donor vitchyznianoi ta zarubizhnykh ekonomik. Finansy Ukrainy, (4), 41-55.

14. Ofitsiinyi sait Derzhavnoi sluzhby statystyky Ukrainy. (2019). Retrieved June 27, 2019, from http://www.ukrstat.gov.ua/.

Received 2 July 2019

Approved 16 July 2019

Цитування згідно ДСТУ 8302:2015

Нікішина О.В. Принципи формування логістичних ланцюгів товарних ринків: конвергенція підходів // Економіка харчової промисловості. 2019. Т.11, вип. 3. С. 3-15. doi: 10.15673/fie.v11i3.1456

Cite as APA style citation

Nikishyna, O. (2019). Principles of formation of the logistic chains of commodity markets: convergence of approaches. Food Industry Economics, 11(3), 3-15. doi: 10.15673/fie.v11i3.1456 